\title{
Analisis Jalur Pada Kejadian Kriminalitas di Indonesia Tahun 2018
}

\author{
Aisyah Chairani $\mathbf{P}^{1}$, Ineke Kristin Dwi Astuti ${ }^{2}$, Natalia Panjaitan ${ }^{3}$, Sri Rahayu Y. Sinurat ${ }^{4}$, \\ Risni Julaeni Yuhan ${ }^{5}$ \\ 1,2,3,4,5 Jurusan Statistika Sosial, Politeknik Statistika STIS Jakara \\ Jl. Otto Iskandardinata No 64C Jatinegara, Jakarta Timur, 13330 \\ Email:211709516@stis.ac.id,211709751@stis.ac.id,211709888@stis.ac.id,211710018@stis.ac.id, \\ risnij@stis.ac.id
}

\begin{abstract}
ABSTRAK
Kriminalitas merupakan masalah yang sering terjadi dalam kehidupan sehari-hari dan menyebabkan beberapa pihak tertentu dirugikan baik fisik maupun materi. Menurut perhitungan Badan Pusat Statistik Indonesia, dalam 1 menit 32 detik, terjadi 1 tindakan kriminal di Indonesia. Sementara itu, dari 100.000 orang di Indonesia, 140 orang diantaranya beresiko terkena tindak kejahatan. Tingginya angka kriminalitas tentunya dipengaruhi oleh beberapa faktor, baik sosial maupun ekonomi. Penelitian ini bertujuan untuk mengetahui faktor - faktor yang memengaruhi terjadinya tindakan kriminal di Indonesia. Data yang digunakan merupakan data sekunder yang bersumber dari Badan Pusat Statistik Indonesia yang tertera pada beberapa publikasi yang diterbitkan. Metode analisis yang digunakan adalah analisis jalur. Berdasarkan hasil analisis, jumlah angkatan kerja menganggur dan jumlah penduduk berpengaruh tidak langsung terhadap kriminalitas di Indonesia Sementara, jumlah penduduk miskin, jumlah angkatan kerja menganggur, dan jumlah penduduk secara langsung memengaruhi kriminalitas di Indonesia.
\end{abstract}

Kata Kunci: analisis jalur, kriminalitas, penduduk miskin, pengangguran, regresi linear

\begin{abstract}
Crime is a problem that often occurs everyday and causes certain people to be harmed both physically and materially. According to the calculation of the Indonesian Central Statistics Agency, in 1 minute 32 seconds, 1 criminal act occurred in Indonesia. Meanwhile, out of 100,000 people in Indonesia, 140 of them are at risk of crime. The high crime rate is certainly influenced by several factors, both social and economic. This study aims to determine the factors that influence the occurrence of criminal acts in Indonesia. The data used are secondary data sourced from the Indonesian Central Statistics Agency which are listed in several published publications. The analytical method used is path analysis. Based on the results of the analysis, the number of unemployed workforce and the number of residents indirectly influences crime in Indonesia. Meanwhile, the number of poor residents the number of unemployed workforce, and the number of residents directly influences crime in Indonesia.
\end{abstract}

Keywords: path analysis, criminality, poor resident, unemployment, linear regression

\section{Pendahuluan}

Kriminalitas merupakan suatu tindakan yang dilakukan oleh individu, kelompok ataupun komunitas yang melanggar hukum sehingga mengganggu keseimbangan dan stabilitas sosial dalam masyarakat. Dalam banyak kasus, kejahatan terjadi karena beberapa faktor. Kartono [2] menyebutkan bahwa faktor penyebab kejahatan antara lain faktor biologik, sosiologik, faktor - faktor mental, faktorfaktor fisik, dan faktor - faktor pribadi. Badan Pusat Statistik (BPS) dalam publikasi Statistik Kriminal 2018 mencatat terjadi 336.652 tindak kejahatan di Indonesia pada tahun 2017. Hal ini berarti jumlah orang yang mengalami kejahatan per 100 ribu penduduk (crime rate) mencapai 129 orang.

Dalam penelitian Lumenta dan Kekenusa [4] serta Kosmaryati [3], pengangguran memiliki pengaruh signifikan secara langsung terhadap kriminalitas. Besarnya angka pengangguran mempunyai 
pengaruh sosial yang luas karena mereka tidak memiliki pekerjaan sekaligus tidak memiliki pendapatan. Semakin tinggi jumlah angka pengangguran semakin tinggi pula tingkat kerawanan sosial yang ditimbulkan, contohnya kriminalitas.

Jumlah penduduk berkaitan dengan kepadatan penduduk, kepadatan penduduk akan meningkat seiring dengan peningkatan jumlah penduduk. Dalam buku "Patologi Sosial" oleh Kartono [2], menyebutkan bahwa salah satu penyebab kejahatan antara lain dipengaruhi oleh faktor sosial yaitu kepadatan penduduk. Dalam penelitian Dermawati, dkk [1], jumlah penduduk berpengaruh signifikan secara langsung terhadap peningkatan jumlah kriminalitas.

Menurut Kartono [2], kemiskinan kronis tanpa jalan keluar mengakibatkan banyak orang berputus asa, sehingga kejahatan atau kriminalitas merupakan satu-satunya jalan untuk menolong kehidupan. Meningkatnya jumlah penduduk miskin akan berpengaruh terhadap tingginya jumlah kriminalitas. Hal ini sesuai dengan penelitian Todutua [7] dimana kemiskinan memiliki pengaruh positif terhadap tingkat kejahatan.

Kasus ini akan dikaji dalam suatu analisis statistik yang dapat mendeteksi besarnya faktor - faktor tersebut baik secara langsung maupun tidak langsung terhadap tingkat kriminalitas. Salah satu analisis statatistik yang dapat digunakan untuk menganalisis hubungan sebab akibat dari beberapa variabel adalah analisis jalur (path analysis).

Adapun tujuan yang hendak dicapai dalam penelitian ini adalah:

1. Membentuk model diagram jalur berdasarkan faktor - faktor yang memengaruhi tingkat kriminalitas

2. Menghitung besarnya pengaruh langsung, tidak langsung, dan pengaruh total variabel eksogen terhadap variabel endogen.

\section{Metode dan Bahan Penelitian}

\section{Metode Penelitian}

Penelitian ini menganalisis data menggunaan analisis jalur (path analysis) dengan menggunakan SPSS 24. Data untuk penelitian ini merupakan data sekunder yang di peroleh dari publikasi Badan Pusat Statistik (BPS) tahun 2018. Penelitian ini mencakup semua provinsi yang ada di Indonesia yaitu sebanyak 34 provinsi. Adapun variabel yang digunakan dalam penelitian ini yaitu diberikan pada Tabel 1.

Tabel 1. Definisi operasional variabel

\begin{tabular}{cll}
\hline Nama variabel & Kategori & Keterangan \\
\hline Jumlah kriminalitas & Numerik & Variabel dependent \\
Jumlah angkatan kerja menganggur & Numerik & Variabel independent \\
Jumlah peduduk & Numerik & Variabel independent \\
Junlah penuduk miskin & Numerik & Variabel independent \\
\hline
\end{tabular}

Adapun langkah - langkah dalam melakukan pengolahan data dengan metode ini antara lain:

1. Menggambarkan diagram hubungan antara variabel eksogen dan variabel endogen.

2. Menentukan persamaan struktural di setiap model yang terbentuk

3. Menghitung besarnya pengaruh langsung, pengaruh tidak langsung serta pengaruh total variabel eksogen terhadap variabel endogen secara parsial dengan menggunakan regresi linear.

4. Interpretasi hasil dan pembahasan.

\section{Bahan Penelitian}

\subsection{Analisis Jalur (Path Analysis)}

Dalam buku Rutherford [7] menjelaskan bahwa analisis jalur ialah suatu teknik untuk menganalisis hubungan sebab akibat yang terjadi pada regresi berganda jika variabel bebasnya 
mempengaruhi variabel terikat tidak hanya secara langsung tetapi juga tidak langsung. Peneliti lain, Zhang [8] juga menyebutkan bahwa analisis jalur merupakan pengembangan langsung bentuk regresi berganda dengan tujuan untuk memberikan estimasi tingkat kepentingan (magnitude) dan signifikansi hubungan sebab akibat hipotetikan dalam seperangkat variabel. Jadi dapat disimpulkan oleh Paul [5], analisis jalur merupakan teknik pengembangan dari regresi linear berganda yang digunakan untuk menguji besarnya sumbangan (kontribusi) yang ditunjukkan oleh koefisien jalur pada setiap diagram jalur dari hubungan kausal antar variabel $X_{1}, X_{2}, X_{3}$ terhadap $Y$. Asumsi yang perlu diperhatikan dalam analisis jalur antara lain:

1. Hubungan antara variabel haruslah linear dan aditif

2. Semua variabel residu tidak mempunyai korelasi satu sama lain

3. Pola hubungan antara variabel adalah rekursif (searah)

4. Skala dari semua skala pengukuran variabel adalah minimal interval.

Dalam analisis jalur terdapat dua jenis variabel yaitu variabel eksogen dan variabel endogen. Variabel eksogen dalam suatu model jalur ialah semua variabel yang tidak ada penyebab-penyebab eksplisitnya atau dalam diagram tidak ada anak panah yang menuju kearahnya, selain pada bagian kesalahan pengukuran. Jika antara variabel eksogen dikorelasikan maka korelasi tersebut ditunjukkan dengan anak panah dengan kepala dua yang menghubungkan variabel-variabel tersebut (variabel independent).

Variabel endogen ialah variabel yang mempunyai anak panah menuju kearah variabel yang mempunyai anak panah. Variabel yang termasuk didalamnya ialah mencakup semua variabel perantara dan tergantung. Variabel perantara endogen mempunyai anak panah yang menuju kearahnya dan dari arah variabel tersebut dalam suatu model diagram jalur. Sedangkan variabel tergantung hanya mempunyai anak panah yang menuju kearahnya, atau dapat disebut juga sebagai variabel dependent.

\section{Hasil dan Pembahasan}

\section{Gambaran Umum}

Berdasarkan hasil pengolahan data, variabel- variabel yang digunakan dalam penelitian ini di analisis untuk melihat gambaran secara umum di Indonesia.

\subsection{Kriminalitas di Indonesia}

Badan Pusat Statistik (BPS) dalam Statistik Kriminal 2018 mencatat sebanyak 336.652 tindak kejahatan (kriminalitas) di Indonesia pada tahun 2018. Jumlah orang yang mengalami tindak kejahatan per 100 ribu penduduk (crime rate) mencapai 129 orang. Gambar 1 menunjukkan penyebaran kriminalitas pada masing-masing provinsi di Indonesia. Jumlah kriminalitas berdasarkan kategori tinggi, sedang dan rendah masing-masing sebanyak 4, 18, dan 12 provinsi.

Provinsi dengan jumlah kriminal tertinggi adalah Provinsi DKI Jakarta sebanyak 34.655 kasus kriminalitas atau sekitar 11,78\% dari seluruh kasus kriminalitas di Indonesia. Sedangkan Provinsi Kalimantan Utara adalah provinsi dengan jumlah kriminalitas terendah dimana hanya 396 kasus kiminalitas atau sekitar 0,13\% dari seluruh kasus krimanitas di Indonesia. 


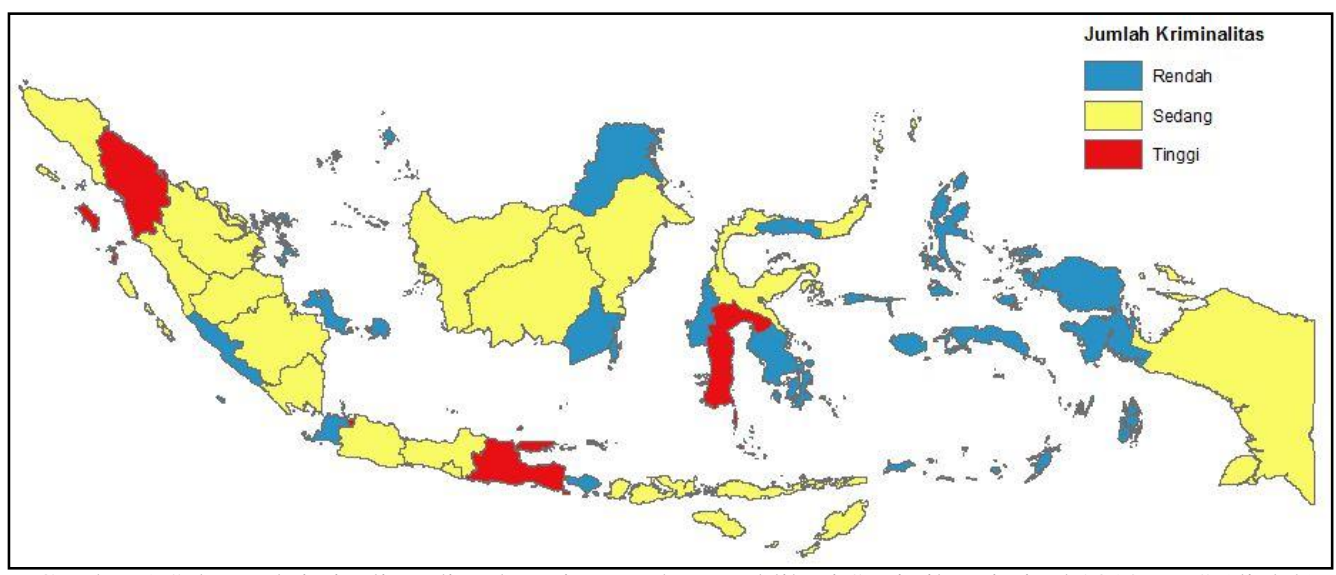

Gambar 1.Sebaran kriminalitas di Indonesia, sumber : publikasi Statistik Kriminal 2018, BPS (diolah).

\subsection{Pengangguran di Indonesia}

Pengangguran merupakan masalah yang terjadi hampir di semua negara termaksud di Indonesia. Tingkat Pengangguran Terbuka (TPT) di Indonesia mengalami penurunan sejak tahun 2015 sampai dengan tahun 2018. Pada Agustus 2018, TPT turun menjadi 5,34\% dibandingkan tahun lalu yang sebesar 5,50\%.

Dalam penelitian ini, jumlah angkatan kerja menganggur memiliki peran dalam tindakan kriminalitas di Indonesia. Dari Gambar 2 dapat dilihat bahwa jumlah angkatan kerja menganggur tertinggi adalah Provinsi Jawa Barat yaitu sebesar 26,40\% dari keseluruhan angkatan kerja menganggur yang ada Indonesia. Provinsi Kalimantan Utara adalah provinsi dengan jumlah angkatan kerja menganggur yang terendah yaitu $0,25 \%$ dari keseluruhan angakatan kerja menganggur di Indonesia.

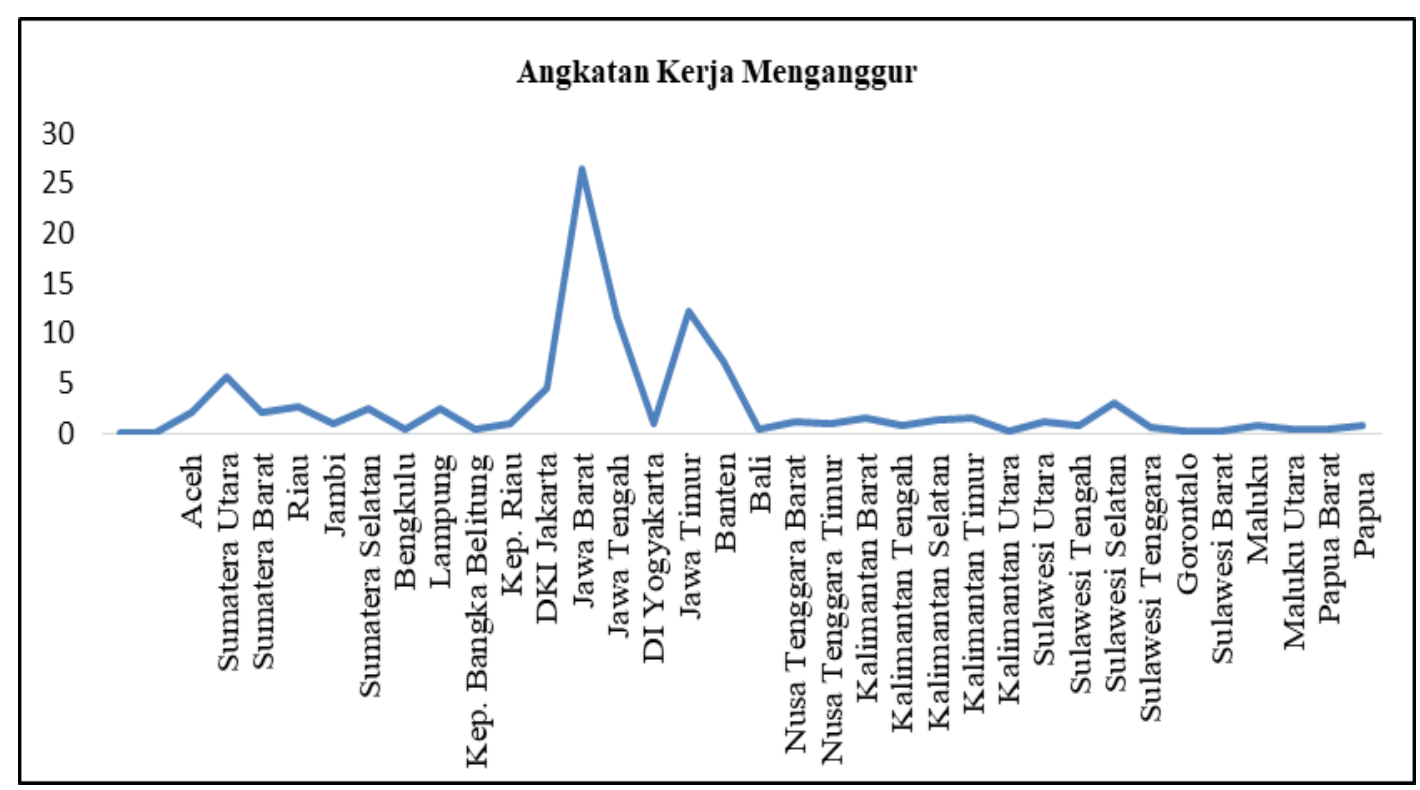

Gambar 2. Persentase jumlah angkatan kerja menganggur berdasarkan provinsi di Indonesia tahun 2018. Sumber: publikasi Statistik Kriminal 2018, BPS (diolah). 


\subsection{Jumlah Penduduk dan Penduduk Miskin di Indonesia}

Badan Pusat Statistik (BPS) memprediksi jumlah penduduk Indonesia akan mencapai 319 juta jiwa pada 2045 mendatang. Artinya, jumlah penduduk Indonesia akan meningkat sebesar 54 juta jiwa dibandingkan total keseluruhan penduduk tahun 2018 yaitu 265 juta jiwa. Jadi, peningkatan jumlah penduduk akan meningkatkan jumlah penduduk miskin yang ada Indonesia.

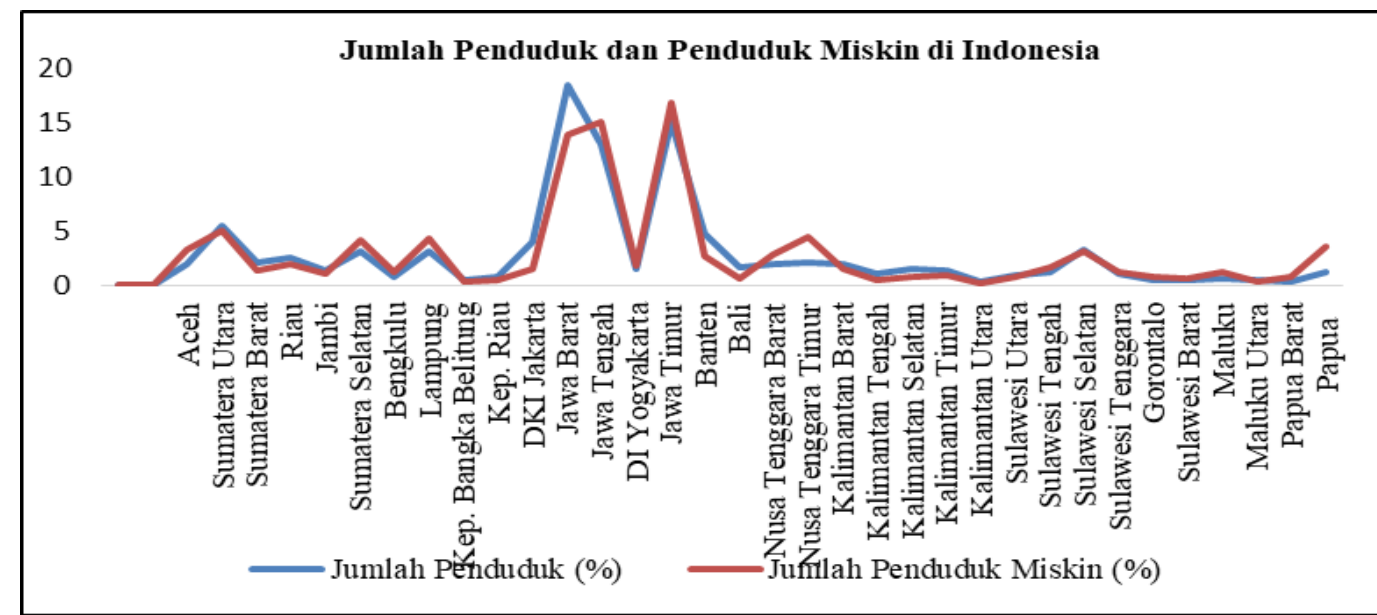

Gambar 3. Persentase jumlah penduduk dan penduduk miskin berdasarkan provinsi di Indoneia tahun 2018. Sumber : Badan Pusat Statistik (diolah).

Jumlah penduduk miskin di Indonesia pada September 2018 sebanyak 25,67 juta jiwa. Adapun tingkat kemiskinan tahun 2018 sebesar 9,82\%. Dari Gambar 3 dapat dilihat bahwa jumlah penduduk yang tertinggi terdapat pada Provinsi Jawa Barat, 18,34\% dari seluruh jumlah penduduk di Indonesia. Provinsi Kalimantan Utara adalah provinsi dengan jumlah penduduk miskin terendah, 0,26\% dari seluruh jumlah penduduk di Indonesia.

Jika dilihat dari jumlah penduduk miskin maka yang tertinggi adalah Provinsi Jawa Timur, $16,72 \%$ dari keseluruhan jumlah penduduk miskin di Indonesia. Provinsi Kalimantan Utara adalah provinsi dengan jumlah penduduk miskin terendah, 0,19\% dari keseluruhan jumlah penduduk miskin di Indonesia.

\section{Analisis Jalur (Path Analysis)}

Berdasarkan permasalahan yang timbul, maka dapat digambarkan bagaimana diagram jalur secara umum seperti di bawah ini untuk memudahkan pembaca menelaah hubungan antar variabel yang terdapat dalam penelitian ini.

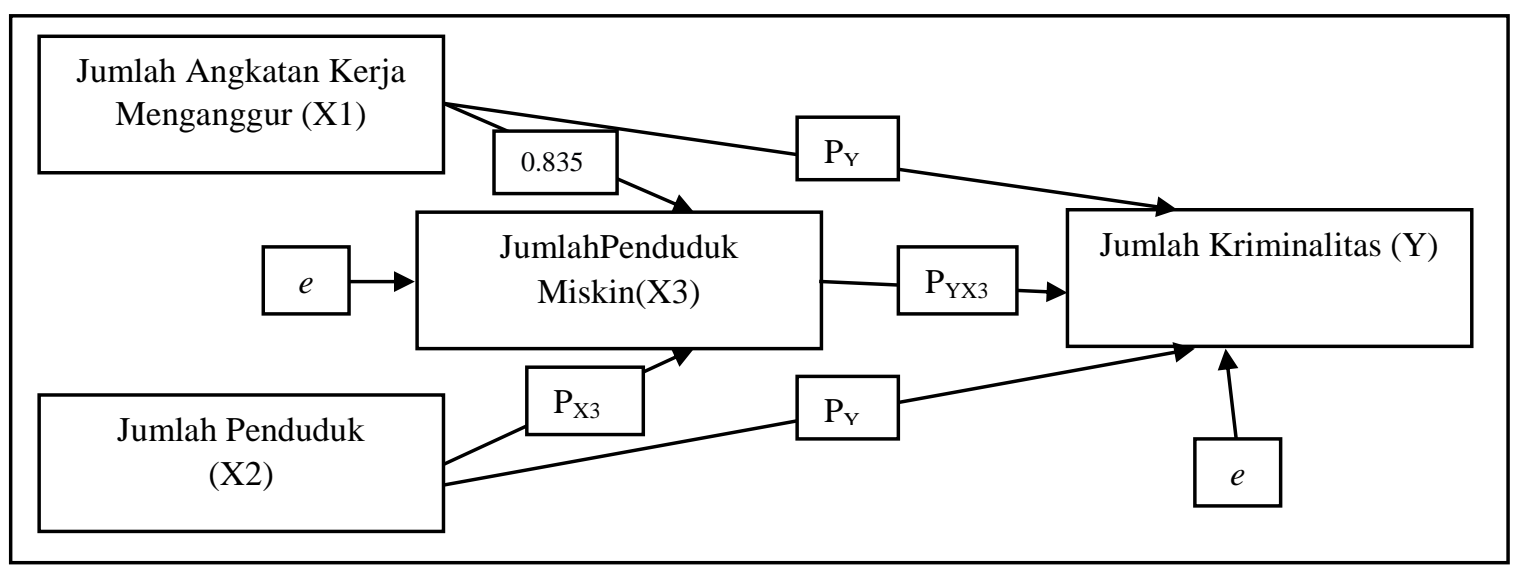

Gambar 4.Diagram jalur determinan kriminalitas. 


\subsection{Model Struktural 1}

Penghitungan dan Pengujian Koefisien Jalur:

Hipotesis:

$H_{01}: P_{x 3 x 1}=0$
$H_{02}: P_{x 3 x 2}=0$
$H_{11}: P_{x 3 x 1} \neq 0$
$H_{12}: P_{x 3 x 2} \neq 0$

Tabel 2. Ringkasan hasil estimasi parameter dan signifikansi koefisien jalur pada model struktural

\begin{tabular}{|c|c|c|c|c|c|c|}
\hline Model & Variabel & $\begin{array}{c}\text { Koefisien } \\
\text { terstandardisasi (Beta) }\end{array}$ & $\begin{array}{l}\text { Nilai } t \\
\text { hitung }\end{array}$ & $\begin{array}{c}P- \\
\text { value }\end{array}$ & $R$-square & $\begin{array}{l}\text { Adjusted } R- \\
\text { square }\end{array}$ \\
\hline $\begin{array}{l}\text { Model } \\
\text { struktural }\end{array}$ & $\begin{array}{l}\text { Jumlah angkatan kerja } \\
\text { menganggur }\left(X_{l}\right)\end{array}$ & $-0,835$ & $-6,619$ & 0,000 & \multirow[t]{2}{*}{0,958} & \multirow[t]{2}{*}{0,955} \\
\hline 1 & Jumlah penduduk $\left(\mathrm{X}_{2}\right)$ & 1,746 & 13,843 & 0,000 & & \\
\hline
\end{tabular}

Dari Tabel 2, diperoleh nilai signifikansi untuk jumlah angkatan kerja menganggur terhadap jumlah penduduk miskin 0,000 sedangkan nilai signifikansi untuk jumlah penduduk terhadap jumlah penduduk miskin 0,000. Kedua nilai tersebut lebih kecil jika dibandingkan dengan taraf signifikansi yang digunakan dalam penelitian ini, yaitu $10 \%(0,000<0,1)$. Sehingga didapatkan keputusan tolak $\mathrm{H}_{0}$. Kesimpulannya, dengan taraf signifikansi $10 \%$, dapat dikatakan bahwa variabel jumlah angkatan kerja menganggur dan variabel jumlah penduduk masing-masing signifikan mempengaruhi jumlah penduduk miskin secara langsung.

Besarnya nilai $R^{2}$ dari Tabel 2 di atas adalah 0,958 yang berarti ketika digunakan secara bersama sama, variabel jumlah angkatan kerja menganggur dan jumlah penduduk memiliki kontribusi terhadap variabel jumlah penduduk miskin sebesar $95,8 \%$ sedangkan 4,2\% sisanya dipengaruhi oleh variabel lain yang tidak tercakup dalam penelitian. Sementara itu, nilai $e_{1}$ didapat dari rumus $\sqrt{1-R^{2}}$ yaitu sebesar 0,042. Sehingga diagram jalur dari persamaan struktural 1 adalah :

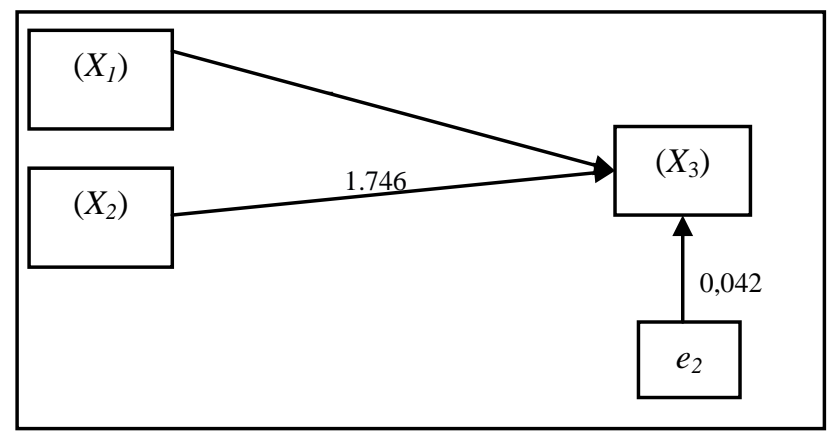

Gambar 5. Diagram jalur persamaan struktural 1

Sehingga persamaan struktural pertama yang terbentuk adalah sebagai berikut:

$$
\begin{aligned}
& X_{3}=P_{x 3 x 1} X_{1}+P_{x 3 x 2} X_{2}+P_{x 3 e 1} \varepsilon_{1} \\
& X_{3}=-0,835 X_{1}+1,746 X_{2}+0,042 .
\end{aligned}
$$




\subsection{Model Struktural 2}

Penghitungan dan Pengujian Koefisien Jalur:

Hipotesis:

$$
\begin{aligned}
& H_{01}: P_{y x 1}=0 \\
& H_{02}: P_{y x 2}=0 \\
& H_{03}: P_{y x 3}=0 \\
& H_{11}: P_{y x 1} \neq 0 \\
& H_{12}: P_{y x 2} \neq 0 \\
& H_{13}: P_{y x 3} \neq 0
\end{aligned}
$$

\begin{tabular}{|c|c|c|c|c|c|c|}
\hline & Variabel & $\begin{array}{c}\text { Koefisien } \\
\text { terstandardisasi } \\
\text { (Beta) }\end{array}$ & $\begin{array}{l}\text { Nilai } t \\
\text { hitung }\end{array}$ & P-value & $R$-square & $\begin{array}{l}\text { Adjusted } \\
R \text {-square }\end{array}$ \\
\hline \multirow{3}{*}{$\begin{array}{l}\text { Model } \\
\text { struktural } \\
2\end{array}$} & $\begin{array}{l}\text { Jumlah angkatan kerja } \\
\text { menganggur }\left(X_{l}\right)\end{array}$ & $-1,684$ & $-2,181$ & 0,037 & \multirow{3}{*}{0,367} & \multirow{3}{*}{0,303} \\
\hline & Jumlah penduduk $\left(X_{2}\right)$ & 3,462 & 2,598 & 0,014 & & \\
\hline & $\begin{array}{l}\text { Jumlah penduduk miskin } \\
(Y)\end{array}$ & $-1,414$ & $-1,998$ & 0,055 & & \\
\hline
\end{tabular}

Tabel 3. Ringkasan hasil estimasi parameter dan signifikansi koefisien jalur pada model struktural

Dari Tabel 3, diperoleh nilai signifikansi terhadap jumlah kriminalitas dari jumlah angkatan kerja menganggur sebesar 0,037, dari jumlah penduduk sebesar 0,014, dan dari jumlah penduduk miskin sebesar 0,055. Ketiga nilai signifikansi tersebut masing-masing lebih kecil jika dibandingkan dengan taraf signifikansi dalam penelitian ini, yaitu $10 \%(0,37 ; 0,014 ; 0,055<0,1)$ dan diputuskan tolak hipotesis null. Sehingga peneliti dapat menyimpulkan, dengan taraf signifikansi $10 \%$, dapat dikatakan bahwa variabel jumlah angkatan kerja menganggur, jumlah penduduk, dan jumlah penduduk miskin masing-masing signifikan berpengaruh terhadap jumlah kriminalitas secara langsung.

Kemudian jika dilihat dari nilai $R^{2}$ sebesar 0,367, berarti ketika digunakan secara bersama sama, variabel jumlah angkatan kerja menganggur, jumlah penduduk, dan jumlah penduduk miskin memiliki kontribusi terhadap variabel jumlah kriminalitas sebesar 36,7\% sedangkan 63,3\% sisanya dipengaruhi oleh variabel lain yang tidak tercakup dalam penelitian. Sementara itu, nilai $e_{1}$ didapat dari rumus $\sqrt{1-R^{2}}$ yaitu sebesar 0,633 . Sehingga diagram jalur dari persamaan struktural ke-dua adalah

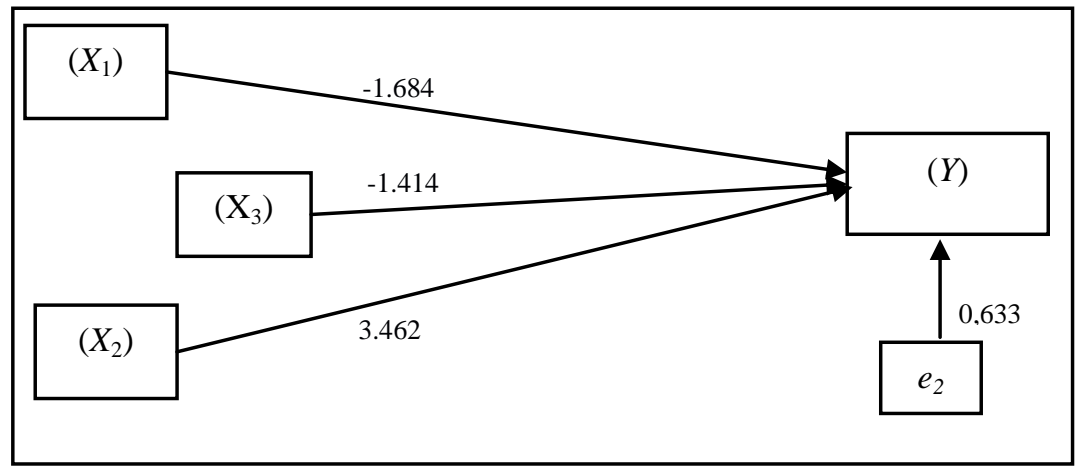

Gambar 6. Diagram jalur persamaan struktural 2.

Sehingga persamaan struktural kedua yang terbentuk adalah sebagai berikut:

$$
\begin{aligned}
& Y=P_{y x 1} X_{1}+P_{y x 2} X_{2}+P_{y x 3} X_{3}+P_{y \in 2} \varepsilon_{2} \\
& Y=-1,684 X_{1}+3,462 X_{2}-1,414 X_{3}+0,633
\end{aligned}
$$




\subsection{Diagram Jalur}

Setelah diperoleh nilai seluruh koefisien jalur dalam model, maka dapat digambarkan bahwa secara umum, diagram jalur yang terbentuk adalah seperti yang terdapat pada gambar berikut

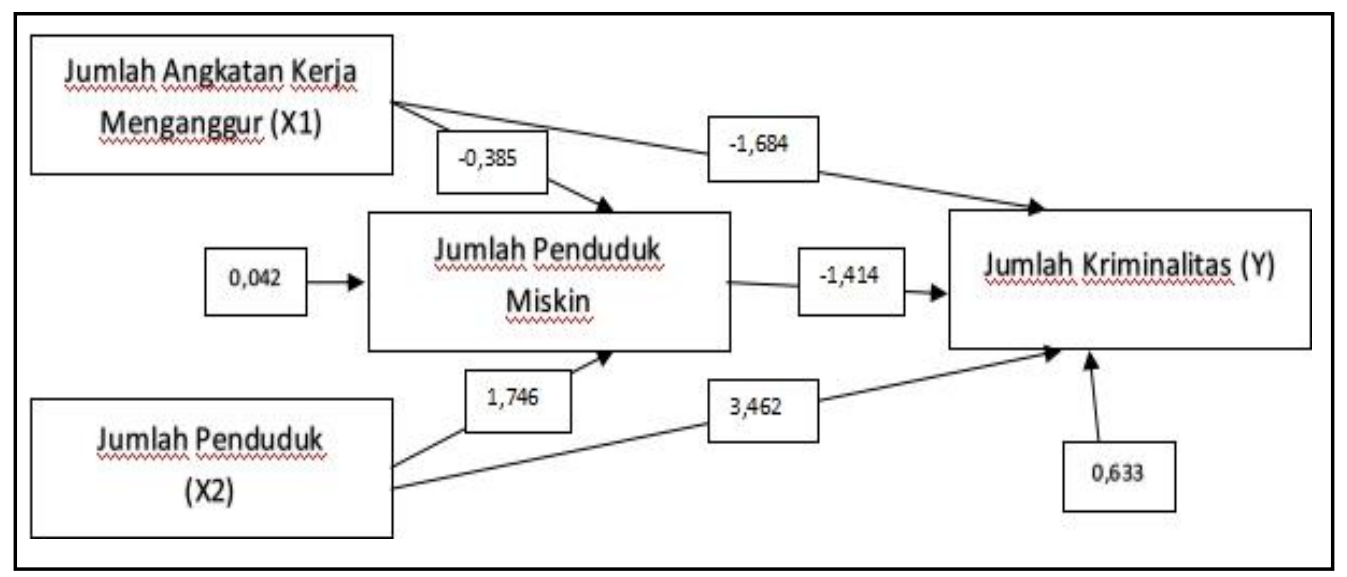

Gambar 7. Diagram jalur determinan jumlah kriminalitas secara umum.

\subsection{Pengaruh Variabel Independent Terhadap Variabel Dependent}

Tabel 4. Pengaruh variabel $X_{1}, X_{2}$, dan $X_{3}$ terhadap variable $Y$

\begin{tabular}{cccc}
\hline $\begin{array}{c}\text { Hubungan } \\
\text { variabel }\end{array}$ & Pengaruh langsung & Pengaruh tidak langsung & Pengaruh total \\
\hline $\mathrm{X}_{1}-\mathrm{Y}$ & 2,8359 & 1,1807 & 4,0166 \\
\hline $\mathrm{X}_{2}>\mathrm{Y}$ & 11,9854 & $-2,4688$ & 9,5166 \\
\hline $\mathrm{X}_{3}>\mathrm{Y}$ & 1,9994 & - & 1,9994 \\
\hline$X_{1}:$ Jumlah angkatan kerja menganggur, $X_{2}:$ jumlah penduduk, $X_{3}:$ jumlah penduduk miskin, \\
$Y:$ jumlah kriminalitas
\end{tabular}

Dari Tabel 4 di atas, diperoleh pengaruh total variabel jumlah angkatan kerja terhadap jumlah kriminalitas adalah 4,0166. Kemudian pengaruh total dari variabel jumlah penduduk terhadap jumlah kriminalitas sebesar 9,5166. Dan pengaruh total dari variabel jumlah penduduk miskin terhadap jumlah kriminalitas sebesar 1,9994. Maka dapat disimpulkan bahwa variabel yang memiliki pengaruh terbesar terhadap banyaknya jumlah kriminal adalah variabel jumlah penduduk. Yang berarti, secara umum apabila Indonesia memiliki jumlah penduduk yang bertambah banyak, maka berpotensi menambah banyaknya kasus kriminal yang terjadi pula di Indonesia.

\section{Kesimpulan}

Jumlah kriminalitas dapat dipengaruhi secara tidak langsung oleh jumlah angkatan kerja menganggur dan jumlah penduduk melalui jumlah penduduk miskin. Jumlah kriminalitas dapat dipengaruhi secara langsung oleh jumlah angkatan kerja menganggur, jumlah penduduk dan jumlah penduduk miskin.

Variabel jumlah penduduk adalah variabel yang paling besar pengaruhnya terhadap jumlah kriminalitas di Indonesia dibandingkan variabel bebas lainnya. Semakin tinggi jumlah penduduk maka akan berpotensi menambah jumlah kriminalitas di Indonesia. 


\section{Daftar Pustaka}

[1] Dermawanti., dkk., Faktor - Faktor Mempengaruhi Kriminalitas di Kabupaten Batang Tahun 2013 dengan Analisi Jalur, Jurnal Gaussian, 4(2), 2015. 247-256.

[2] Kartono, Patologi Sosial, Raja Grafindo Persada, Jakarta, 1999.

[3] Kosmaryati,.. dkk, Faktor-Faktor yang Mempengaruhi Kriminalitas di Indonesia Tahun 2011-2016 dengan Regresi Data Panel, Indonesia Journal of Applied Statistics, 2(1).

[4] Lumenta, C.Y \& Kekenusa, J.S, Analisis Jalur Faktor-Faktor Penyebab Kriminalitas di Kota Manado, Universitas Sam Ratulangi, 2012.

[5] Paul, dkk., Path Analysis, Universitas Exeter, Inggris, 1997.

[6] Rutherford, R.D., Statistical Model For Causal Analysis, John Wiley \& Sons Inc, New York

[7] Todutua, D.S,. Pengaruh Kemiskinan, Kepadatan Penduduk, Tingkat Penyelesaian Kasus, dan Jumlah Polisi Terhadap Tingkat Kejahatan Properti DKI Jakarta, Universitas Dipenogoro, 2016.

[8] Zhang, W., Learning Variables In Class Laptop Multitasking and Academic Performance: A path analysis, Jurnal Computer dan Education, 81, 2015. 82-88 